\title{
A FULL FACTORIAL DESIGN IN THE FORMULATION OF DIAZEPAM PARENTERAL NANOEMULSIONS: PHYSICOCHEMICAL CHARACTERIZATION AND STABILITY EVALUATION
}

Nebojša D. Cekić1,2, Sanela M. Đorđevićc ${ }^{3,}$, Saša R. Savić1, Snežana D. Savić ${ }^{3}$

${ }^{1}$ Faculty of Technology, University of Niš, Leskovac, Serbia

${ }^{2}$ DCP Hemigal, Leskovac, Serbia

${ }^{3}$ Department of Pharmaceutical Technology and Cosmetology, Faculty of Pharmacy, University of Belgrade, Belgrade, Serbia

Using the experimental design methodology, we have developed and characterized nanoemulsions for a parenteral delivery using diazepam as a model drug. The formulations containing 20 or $30 \%(\mathrm{w} / \mathrm{w})$ of medium chain triglycerides or the mixture of medium chain triglycerides and soybean oil as the oil phase, soybean lecithin and polysorbate 80 as emulsifiers, and a phosphate buffer solution as the aqueous phase were prepared by cold high pressure homogenization. The obtained nanoemulsions were evaluated in terms of droplet size, size distribution, surface charge, drug-vehicle interactions and physical stability. To evaluate the effects of the oil phase type, oil content and drug presence, as well as their interactions on critical quality attributes of nanoemulsions, a three-factor two-level full factorial design was applied.

After the preparation, all nanoemulsions revealed small spherical droplets in the range 170-210 $\mathrm{nm}$, with the narrow droplet size distribution $(<0.15)$ and the surface charge about $-60 \mathrm{mV}$. The experimental design results indicated that not only factors alone (oil type, oil content, presence of drug), but their interactions also had a significant effect on the nanoemulsion droplet size, polydispersity index, and zeta potential. During two months of storage at $25^{\circ} \mathrm{C}$, all nanoemulsions formulated with the medium chain triglycerides-soybean oil mixture $(4: 1, w / w)$ remained physically stable, without considerable changes in monitored parameters. Physicochemical characteristics and stability of these nanoemulsions demonstrated their suitability for parenteral drug delivery.
(ORIGINAL SCIENTIFIC PAPER)

UDC 615.214.24

Keywords: nanoemulsion; diazepam; experimental design; parenteral delivery; physical stability.

\section{Introduction}

During the last decades, there has been a renewed and growing interest in developing nanoemulsions as promising colloidal drug carriers for different routes of administration, especially for parenteral application. Considering the formulation and physicochemical characteristics, nanoemulsions have been associated with a number of advantages such as a low surfactant concentration, a uniform and very small droplet size, low viscosity, and high solubilization capacity for lipophilic drugs. Additionally, the improved penetration through biological barriers, possible enhanced bioavailability and organ targeting could be expected with these systems [1-6]. Although lipid nanoemulsions have been traditionally employed for parenteral nutrition and intravenous delivery of lipophilic drugs - with several approved products on the market - the additional efforts are required to optimize nanoemulsion formulation, stability, and overall drug delivery $[1,7]$.

It is well known that both formulation parameters and processing conditions, as well as the way of the drug incorporation into the internal oil phase of the nanoemulsion may affect its physicochemical properties and stability [6,8-11]. In order to efficiently investigate a simultaneous effect of different variables that are critical for obtaining nanoemulsions with desired/required characteristics, a design of experiments approach could be a useful tool. However, until now only a few studies have investigated the influence of the formulation and/or processing factors on nanoemulsion properties and stability using this methodology $[8,12,13]$.

Following such considerations, the present paper was aimed at formulating lecithin and polysorbate 80-containing parenteral nanoemulsions using diazepam, a lipophilic poorly water-soluble compound, as a model drug. For this purpose, placebo and drug-loaded nanoemuIsions were designed with the aid of experimental design, prepared by high pressure homogenization (HPH) and characterized in terms of the droplet size, size distribution, surface charge and drug-vehicle interactions. A full factorial experimental design was applied for the identification of the significant main and interaction effects of experimental factors (oil type, oil concentration and

\footnotetext{
* Author address: Sanela M. Đorđević, Department of Pharmaceutical Technology and Cosmetology, Faculty of Pharmacy, University of Belgrade, Vojvode Stepe 450, 11221 Belgrade, Serbia

E-mail: sanela.djordjevic@pharmacy.bg.ac.rs

The manuscript received: April, 14, 2015

Paper accepted: May, 14, 2015.
} 
the presence of drug) in order to find optimal conditions leading to nanoemulsions with desired physicochemical features. In addition, a physical stability of the obtained nanoemulsions during two months of storage at room temperature was also investigated.

\section{Materials and methods}

\section{Materials}

For the preparation of nanoemulsions, the following ingredients were used: diazepam (DZM) (Galenika a.d., Serbia), medium-chain triglycerides (MCT) (Fagron $\mathrm{GmbH} \& \mathrm{KG}$, Germany), soybean oil (SO) (Lipoid $\mathrm{GmbH}$ Germany), soybean lecithin (Lipoid S75; Lipoid $\mathrm{GmbH}$ ), polysorbate 80 (Sigma-Aldrich $\mathrm{GmbH}$, Germany), butylhydroxytoluene (BHT) (Sigma-Aldrich $\mathrm{GmbH}$ ), glycerol (Merck KGaA, Germany), and 0.1 M phosphate buffer solution (PBS, pH 8). The water used in the preparation of formulations was double-distilled whereas ultra-pure water, used in analyses, was obtained with a GenPure apparatus (TKA Wasseranfbereitungssysteme $\mathrm{GmbH}$, Germany). All other chemicals and reagents used were of pharmaceutical or HPLC grade.

\section{Preparation of nanoemulsions}

All nanoemulsions were prepared by cold HPH according to the recently published procedure [8]. Briefly, the oil and the aqueous phases were separately prepared. The oil phase, consisting of oil (pure MCT or MCT:SO mixture at the mass ratio of 4:1), lipophilic emulsifier (soybean lecithin) and antioxidant (BHT) was heated at $70^{\circ} \mathrm{C}$ under slight stirring (RH basic 2 IKAMAG ${ }^{\circledR}$ Magnetic Stirrer, IKA ${ }^{\circledR}$-Werke $\mathrm{GmbH}$ \& Co. KG, Germany), until lecithin was completely dissolved. The obtained oil phase was then allowed to cool down to the room temperature $\left(25^{\circ} \mathrm{C}\right)$ and afterwards DZM was added and dissolved in the oil phase. The aqueous phase was prepared by dissolving hydrophilic emulsifier (polysorbate 80 ) in $0.1 \mathrm{M} \mathrm{PBS}(\mathrm{pH}$ 8 ). To adjust isotonicity, glycerol was added to the aqueous phase which was kept at $25^{\circ} \mathrm{C}$.

The phases were combined by adding the aqueous phase to the oil phase, both being kept at $25^{\circ} \mathrm{C}$, and further pre-homogenized with a rotor-stator homogenizer IKA Ultra-Turrax ${ }^{\circledR}$ T25 digital $\left(\right.$ IKA $^{\circledR}$-Werke $\mathrm{GmbH}$ \& Co. KG, Germany) at 8000 rpm for $3 \mathrm{~min}$. The obtained coarse emulsion was subsequently homogenized with a high-pressure homogenizer (EmulsiFlex-C3, Avestin Inc., Canada) at 500 bar for 9 repeated cycles. The resulting nanoemulsion was aseptically filtered through $0.22 \mu \mathrm{m}$ membrane filter and filled into crimped glass vials. Blank nanoemulsions were also prepared according to the above procedure without DZM. All formulations were stored at $25^{\circ} \mathrm{C}$ and one day after preparation their characterization was performed. All measurements were done in triplicate. Code names and compositions of all developed nanoemulsions are given in Table 1.

\section{Full factorial experimental design}

During the nanoemulsion development, a two-level $2^{3}$ full factorial experimental design was used to identify and estimate the main and interaction effects of three different formulation factors (oil type - A, oil content $B$, and presence of model drug $-C$ ) on critical quality attributes of the developed nanoemulsions. Each factor was varied at two coded $(-1,+1)$ levels, in which the -1 level corresponds to the lower value and +1 to the upper value of each independent variable (Table 2). According to the applied design, a total of eight experimental runs were generated and randomly performed. As the response variables, the nanoemulsion droplet size (ZAve), polydispersity index (PDI), and zeta potential (ZP) were determined. The factorial design matrix and the responses of each experiment are shown in Table 3. To fit the experimental data, a first-order polynomial (factorial) model was applied (Eq. (1)):

$Y=\beta_{0}+\beta_{1} A+\beta_{2} B+\beta_{3} C+\beta_{12} A B+$

$+\beta_{13} A C+\beta_{23} B C+\beta_{123} A B C$

where $Y$ is the measured response or dependent variable, $\beta_{0}$ is the intercept, $\beta_{1}, \beta_{2}$ and $\beta_{3}$ are the linear coefficients of the respective independent variables $(A, B, C)$, and $\beta_{12}, \beta_{13}, \beta_{23}$ and $\beta_{123}$ are the interaction coefficients associated with respective model factor interactions $(A B$, $A C, B C, A B C)$. The results obtained for each response were statistically evaluated using Design-Expert software (Stat-Ease Inc., Minnesota, USA). A probability value less than 0.05 was considered to be significant. Interaction plots and three-dimensional response surface plots displaying evaluated responses (Z-Ave, PDI, ZP) at different factor level combinations were also constructed.

\section{Nanoemulsion characterization}

Droplet size and size distribution analysis

The mean droplet size (intensity weighted mean diameter, Z-average diameter, Z-Ave) and droplet size distribution (polydispersity index, PDI) of nanoemulsions were determined by photon correlation spectroscopy (PCS), using a Zetasizer Nano ZS90 (Malvern Instruments Ltd., UK). Before the measurement, each nanoemulsion sample was diluted with freshly prepared $0.1 \mathrm{M}$ PBS (1:500, v/v). The measurements were performed at $25^{\circ} \mathrm{C}$ at a fixed scattering angle of $90^{\circ} \mathrm{C}$ using a $\mathrm{He}-\mathrm{Ne}$ laser at $633 \mathrm{~nm}$.

\section{Zeta potential analysis}

The droplet surface charge of nanoemulsions was determined using a Zetasizer Nano ZS90 (Malvern Instruments Ltd.) by measuring the electrophoretic mobility of nanoemulsion droplets, which was converted to the ZP using in-built software. The measurements were performed at $25^{\circ} \mathrm{C}$ immediately upon the appropriate dilution of the samples $(1: 500, v / v)$ with the electrolyte solution consisting of ultra-pure water with constant conductivity (about $50 \mu \mathrm{S} / \mathrm{cm}$ ) adjusted by $0.1 \mathrm{M}$ PBS. 
Electrical conductivity measurements

The electrical conductivity of all samples was determined using a CDM230 Conductivity Meter (Radiometer, Denmark). The measurements were performed at $25^{\circ} \mathrm{C}$ by direct immersion of electrode into the sample.

$\mathrm{pH}$ value measurements

The $\mathrm{pH}$ values of all nanoemulsions were determined using a HI9321 pH meter (Hanna Instruments Inc., Michigan, USA). The measurements were performed at $25^{\circ} \mathrm{C}$ by direct immersion of $\mathrm{pH}$ meter glass electrode into the samples.

\section{Differential scanning calorimetry}

To evaluate the physical state of DZM in formulated nanoemulsions and possible interactions between the drug and other components, the differential scanning calorimetry (DSC) was performed. The DSC thermograms of pure DZM, DZM-loaded and blank nanoemulsions were recorded using a Mettler DSC 820 apparatus (Mettler Toledo GmbH Analytical, Germany). The samples (about $7 \mathrm{mg}$ ) were accurately weighed in standard aluminum pans, hermetically sealed and scanned between $25^{\circ} \mathrm{C}$ and $200^{\circ} \mathrm{C}$ at a heating rate of $10^{\circ} \mathrm{C} / \mathrm{min}$ under the constant nitrogen flow. An empty aluminum pan was used as a reference. Thermoanalytical parameters, such us enthalpy, onset temperature and peak temperature were calculated using the Mettler Toledo STAR ${ }^{\mathrm{e}}$ software.

\section{Fourier transform infrared spectroscopy}

To investigate any chemical interaction among the incorporated drug and other ingredients, the Fourier transform infrared (FTIR) spectroscopy was also conducted. The FTIR spectra of pure nanoemulsion components, DZM-loaded and blank nanoemulsions were obtained using a BOMEM Hartmann \& Braun MB-Series FTIR spectrophotometer (ABB Bomem Inc., Canada). Prior to FTIR studies, the sample of the pure drug was prepared using the potassium bromide $(\mathrm{KBr})$ pastille method. For the nanoemulsion sample preparation, $10 \mu \mathrm{L}$ of nanoemulsion was placed on the KRS-5 plate and dried in vacuum. The FTIR spectra of all samples were recorded between 4000 and $400 \mathrm{~cm}^{-1}$, using 10 scans for each spectrum, with a resolution of $4 \mathrm{~cm}^{-1}$.

\section{Stability study}

To evaluate the physical stability of the developed nanoemulsions, all formulations were stored at $25^{\circ} \mathrm{C}$ for two months. The nanoemulsion Z-Ave, PDI, ZP, pH and electrical conductivity were determined using the previously described techniques. Statistical analysis of differences in measured parameters (one day after the production and after two months of storage) was performed using Student's t-test. The $p$ value of 0.05 was taken as the level of significance.

\section{Results and discussion}

Preparation and characterization of nanoemulsions

Bearing in mind the specificity and sensitivity of parenteral route of administration, a special attention of the present investigation was paid to the selection of highly safe and biocompatible excipients, especially oils and emulsifiers, to be involved in the nanoemulsion formulation. Concerning the oil phase, MCT and SO, as the most widely used oils in the commercially available parenteral lipid emulsions [1,14] were selected, whereas lecithin and polysorbate 80 were used as emulsifiers for the nanoemulsion preparation. The oil-emulsifier ratio was kept constant at 5:1 (w/w) in all formulations. In order to avoid $\mathrm{pH}$ alterations during storage and to keep DZM as a weak base in the inner oil phase, a $0.1 \mathrm{M} \mathrm{PBS}(\mathrm{pH} 8)$ was chosen as the aqueous phase of the nanoemulsions.

Once the appropriate nanoemulsion components were chosen, a total of eight different formulations (Table 1) concordant with the applied experimental design (Tables 2 and 3) were prepared using cold HPH in order to avoid drug crystallization and precipitation. After the preparation, all nanoemulsions were highly fluid and homogenous with the milky-white appearance. The results of representative parameters measurements (mean droplet size (Z-Ave), PDI, ZP) are presented in Table 3.

Table 1. Composition of nanoemulsion formulations

\begin{tabular}{lcccccccc}
\hline $\begin{array}{l}\text { Formulation } \\
\text { code }\end{array}$ & DZM & MCT & So & LS75 & BHT & P80 & GLIC & PBS, to \\
\hline P20M & - & 16 & 4 & 2 & 0.05 & 2 & 2.5 & 100 \\
P20MS & - & 16 & 4 & 2 & 0.05 & 2 & 2.5 & 100 \\
P30M & - & 24 & 6 & 3 & 0.05 & 3 & 2.5 & 100 \\
P30MS & - & 24 & 6 & 3 & 0.05 & 3 & 2.5 & 100 \\
D20M & 2 & 16 & 4 & 2 & 0.05 & 2 & 2.5 & 100 \\
D20MS & 2 & 16 & 4 & 2 & 0.05 & 2 & 2.5 & 100 \\
D30M & 2 & 24 & 6 & 3 & 0.05 & 3 & 2.5 & 100 \\
D30MS & 2 & 24 & 6 & 3 & 0.05 & 3 & 2.5 & 100 \\
\hline
\end{tabular}

DZM: diazepam; MCT: medium-chain triglycerides; SO: purified soybean oil; LS75: soybean lecithin; BHT: butylhydroxytoluene; P80: polysorbate 80; GLIC: glycerol; PBS: $0.1 \mathrm{M}$ potassium phosphate buffer solution.

Table 2. Variables and levels (actual, coded) used in $2^{3}$ full factorial design

\begin{tabular}{lcc}
\hline Variables & \multicolumn{2}{c}{ Levels } \\
& Actual & Coded \\
\hline A: Oil phase type & MCT & -1 \\
& MCT:SO mixture & +1 \\
B: Oil phase content (\%) & 20 & -1 \\
& 30 & +1 \\
C: Drug presence (DZM) & No $(0 \mathrm{mg} / \mathrm{g})$ & -1 \\
& Yes $(2 \mathrm{mg} / \mathrm{g})$ & +1
\end{tabular}


Table 3. Full factorial design matrix and physicochemical characteristics of designed nanoemulsions one day after preparation and after two months of storage at $25^{\circ} \mathrm{C}$ (mean $\left.\pm \mathrm{SD}, \mathrm{n}=3\right)$

\begin{tabular}{cccccccc}
\hline \multirow{2}{*}{ Formulation } & \multicolumn{2}{c}{ Variables } & \multicolumn{2}{c}{ Time } & \multicolumn{3}{c}{ Responses } \\
& A & B & C & (days) & Z-Ave $(\mathrm{nm})$ & PDI & ZP $(\mathrm{mV})$ \\
\hline \multirow{2}{*}{ P20M } & -1 & -1 & -1 & 1 & $172.9 \pm 2.9$ & $0.099 \pm 0.029$ & $-58.2 \pm 0.3$ \\
& & & & 60 & n.s. & n.s. & n.s. \\
P20MS & +1 & -1 & -1 & 1 & $207.2 \pm 3.4$ & $0.127 \pm 0.022$ & $-61.2 \pm 1.5$ \\
& & & & 60 & $207.3 \pm 3.1$ & $0.121 \pm 0.022$ & $-61.3 \pm 0.4$ \\
P30M & -1 & +1 & -1 & 1 & $181.2 \pm 3.8$ & $0.119 \pm 0.032$ & $-57.4 \pm 0.6$ \\
& & & & 60 & $182.0 \pm 2.4$ & $0.111 \pm 0.026$ & $-53.3 \pm 1.5^{*}$ \\
P30MS & +1 & +1 & -1 & 1 & $204.2 \pm 1.4$ & $0.145 \pm 0.021$ & $-57.3 \pm 2.5$ \\
& & & & 60 & $203.4 \pm 1.7$ & $0.131 \pm 0.023$ & $-57.3 \pm 0.9$ \\
D20M & -1 & -1 & +1 & 1 & $198.3 \pm 0.9$ & $0.152 \pm 0.017$ & $-61.0 \pm 0.2$ \\
& & & & 60 & $n . s$. & $n . s$. & $n . s$. \\
D20MS & +1 & -1 & +1 & 1 & $204.2 \pm 1.9$ & $0.139 \pm 0.014$ & $-56.6 \pm 1.3$ \\
& & & & 60 & $199.6 \pm 1.5$ & $0.126 \pm 0.015$ & $-60.5 \pm 2.6$ \\
D30M & -1 & +1 & +1 & 1 & $189.7 \pm 3.5$ & $0.138 \pm 0.026$ & $-58.7 \pm 0.8$ \\
& & & & 60 & $194.6 \pm 2.9$ & $0.132 \pm 0.035$ & $-57.3 \pm 1.3$ \\
D30MS & +1 & +1 & +1 & 1 & $207.4 \pm 2.3$ & $0.124 \pm 0.020$ & $-60.3 \pm 2.7$ \\
& & & & 60 & $203.7 \pm 1.7$ & $0.131 \pm 0.025$ & $-60.0 \pm 2.6$ \\
\hline
\end{tabular}

n.s.: not stable (phase separation).

*Significant at $p<0.05$.

For parenteral emulsions, the droplet size and size distribution are critical physicochemical parameters regarding patient safety because larger particles may cause embolism $[2,6,15]$. The mean droplet size of commercial parenteral fat emulsions is usually between 100 and $500 \mathrm{~nm}$ and it is generally required to be smaller than $1 \mu \mathrm{m}$ [14], while the PDI, representing the size distribution width lower than 0.25 represents the acceptable value [16]. In the present study, the PCS particle size analysis (Table 3 ) confirmed that the mean droplet size (Z-Ave) of all prepared nanoemulsions was in nanometer range (172-208 $\mathrm{nm})$, with a relatively narrow particle size distribution (PDI below 0.15), suggesting that developed nanoemulsions were suitable for parenteral use. Beside the droplet size, ZP is another important characteristic of the nanoemulsions and an indicator of the nanoemulsion stability $[6,15]$. Absolute ZP values greater than $30 \mathrm{mV}$ point to good stability, while above $60 \mathrm{mV}$ to the excellent one [16]. As Table 3 shows, all formulations produced revealed a negative ZP values about $-60 \mathrm{mV}$, implying a sufficiently high negative surface charge for droplet-droplet repulsion and thus enhanced nanoemulsion stability.

\section{Full factorial experimental design}

With the purpose of gaining a better perception of how nanoemulsion critical properties are influenced by variations of nanoemulsion composition - type and concentration of oil phase and the presence of model drug - the full factorial experimental design was applied in the present study. Besides understanding the individual effect of the investigated factors, this design of experiments technique also allows to elucidate, with the reduced number of experiments, various interactions between independent variables which could not be detected with a traditional one-factor-at-a-time method $[12,17,18]$.
Table 3 shows the results of representative responses measured for all nanoemulsions that were part of the factorial design. For each dependent variable (Z-Ave, PDI and ZP), the effects corresponding to the investigated factors (oil phase type, oil phase content, drug presence) and factors interactions were calculated and their statistical significance was checked. Factors and interactions with $p<0.05$ were considered significant. The terms with insignificant influence on estimated responses were excluded, except those required to maintain hierarchy, and resulting final response equations in terms of coded factors are given below:

ZAve $(\mathrm{nm})=195.64+10.11 A-0.013 B+4.26 C+$

$+0.063 A B-4.21 A C-1.34 B C+2.89 A B C \ldots$

$P D I=0.130+0.003 A+0.001 B+0.008 C-$

$-0.010 A C-0.008 B C$

$Z P(\mathrm{mV})=-58.84-0.012 A+0.41 B-0.31 C-$

$-0.36 A B+0.71 A C-0.76 B C-1.14 A B C$.

The results of the statistical analysis (analysis of variance, ANOVA) showed that generated models for Z-Ave, PDI and ZP were significant $(p<0.05)$, indicating that three listed responses are well described by the proposed models. The smaller the $p$ value or, in other words, the higher the magnitude of each coefficient, the higher is the respective effect on the response. Experimental design results revealed that the mean droplet size ( $Z$ Ave) of nanoemulsions was significantly affected by the type of oil phase (A) as well as the presence of drug $(C)$, with the oil type having a stronger effect. A positive sign for the coefficients of these model terms in Eq. (2) represented a synergistic effect on Z-Ave, meaning that the droplet size increased by using MCT:SO mixture as the oil phase and by incorporating the drug into the nanoemulsion. In addition, significant interactions were identified between the oil phase type and the drug presence (AC) and between the oil content and the drug presence (BC), as presented in Figs. 1a and 2a, respectively.

From Fig. 1a, it could be seen that when MCT:SO mixture was used instead of MCT, Z-Ave of blank as well as of DZM-loaded nanoemulsions tended to increase, irrespective of the oil content, and this increase was more pronounced in placebo nanoemulsions. Furthermore, Z-Ave of blank nanoemulsions formulated with MCT increased, whereas of DZM-loaded nanoemulsions decreased when the content of oil was increased from 20 to $30 \%$ (Fig. 2b). On the contrary, when MCT:SO mixture was used as the oil phase, the increase of the oil content (from 20 to $30 \%$ ) resulted in the decrease of Z-Ave for blank nanoemulsions, whereas the increase of Z-Ave for DZM-loaded nanoemulsions was observed.

From the present graphs, it can be concluded that nanoemulsions prepared with MCT:SO were more robust regarding the effect of DZM on Z-Ave than those with MCT which appeared more sensitive to the drug pres- 
ence. Generally, it was expected that the incorporation of DZM into nanoemulsion would enlarge the droplet size, since additional lipophilic molecules need to be solubilized in the oil phase [1]. However, the obtained results also imply a possible interaction between DZM and emulsifier layer and, consequently, partial drug localization in the o/w interface leading to the reduction of the surface tension and therefore the droplet size, during the homogenization step [11,19].

During the model fitting procedure, it was found that PDI was significantly dependent on the individually tested variables ( $A, B$, and $C$ ) as well as on their combined effects ( $A C$ and $B C)$. All the studied factors - the oil type, the oil content, and the presence of DZM - were positive, imposing a linear effect on increasing the PDI of nanoemulsions. The results obtained from the interactions are shown in Figs. $1 \mathrm{~b}$ and $2 \mathrm{~b}$. It can be seen that PDI of blank nanoemulsions increased while of DZM-loaded nanoemulsions decreased, when MCT:SO mixture was used instead of MCT as oil phase (Fig. 1b). Furthermore, the increase in the oil content from 20 to $30 \%$ resulted in the increase of PDI for blank nanoemulsions prepared with either pure MCT or MCT:SO mixture. Conversely, for DZM-loaded nanoemulsions, a decrease in PDI was observed (Fig. 2b).

Regarding the ZP, the oil content $(B)$ and the drug presence $(C)$ were found to be significant. The content of oil had a positive influence on nanoemulsion ZP (Eq. (4)) - the lower absolute ZP was obtained at the higher oil content. A negative sign for the coefficient of the drug presence in Eq. (4) represented an antagonistic effect on ZP, meaning that the surface charge of DZM-loaded nanoemulsions was more negative compared to unloaded formulations. Further, not only the investigated factors alone, but also their interactions $(A B, A C$, and $B C)$ were shown to significantly affect the nanoemulsion $Z P$ (Figs. 1c and 2c).

It could be noticed that the increase in the amount of oil from 20 to $30 \%$ showed the increase in absolute ZP of both unloaded and DZM-loaded nanoemulsions prepared with MCT as the oil phase. Conversely, when MCT:SO mixture was used, the absolute ZP of placebo nanoemulsion decreased, while in the DZM-loaded nanoemulsion increased when the content of oil changed from 20 to $30 \%$ (Fig. 1c). Also, it is obvious that the ZP of placebo nanoemulsions was higher (more negative) and of DZM-loaded nanoemulsions lower (more positive), when MCT:SO was employed instead of pure MCT (Fig. 2c).
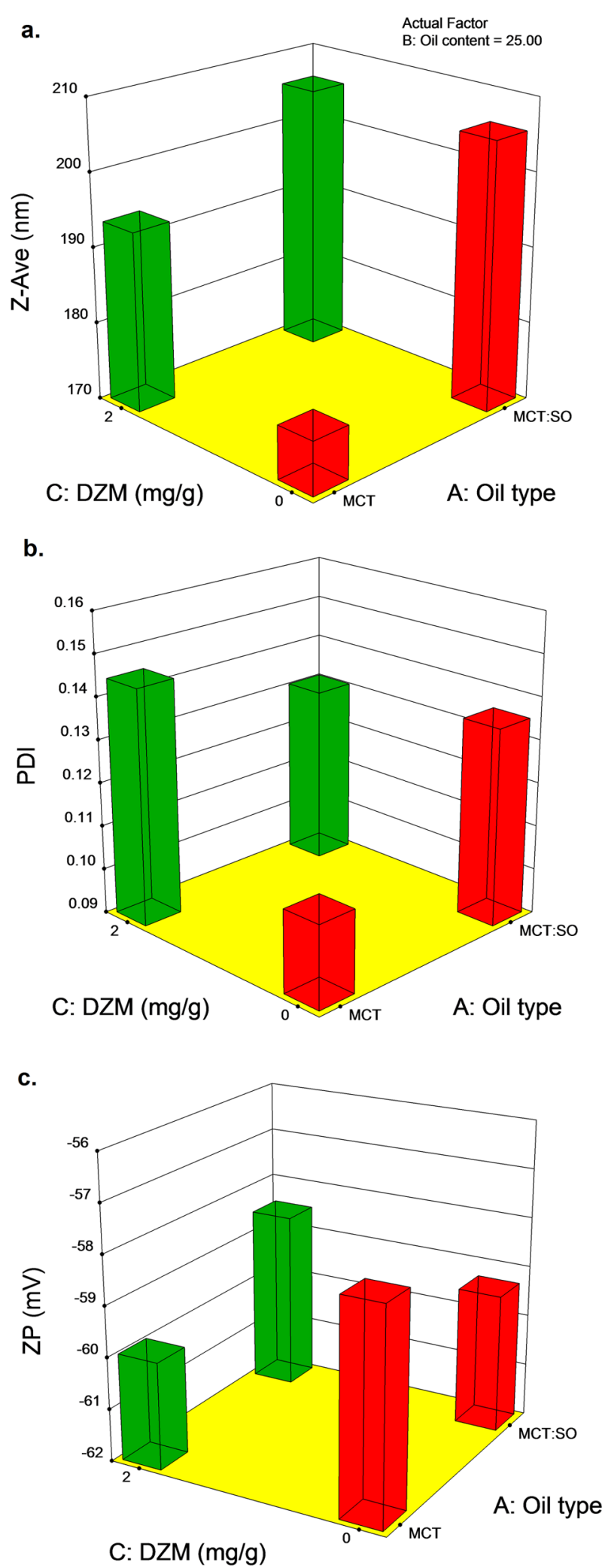

Figure1. Response surface plots showing the effects of $A$ (oil phase type) and $C$ (drug presence) on the Z-Ave (a), PDI (b), and ZP (c) of nanoemulsions at the middle level of B (oil content). 

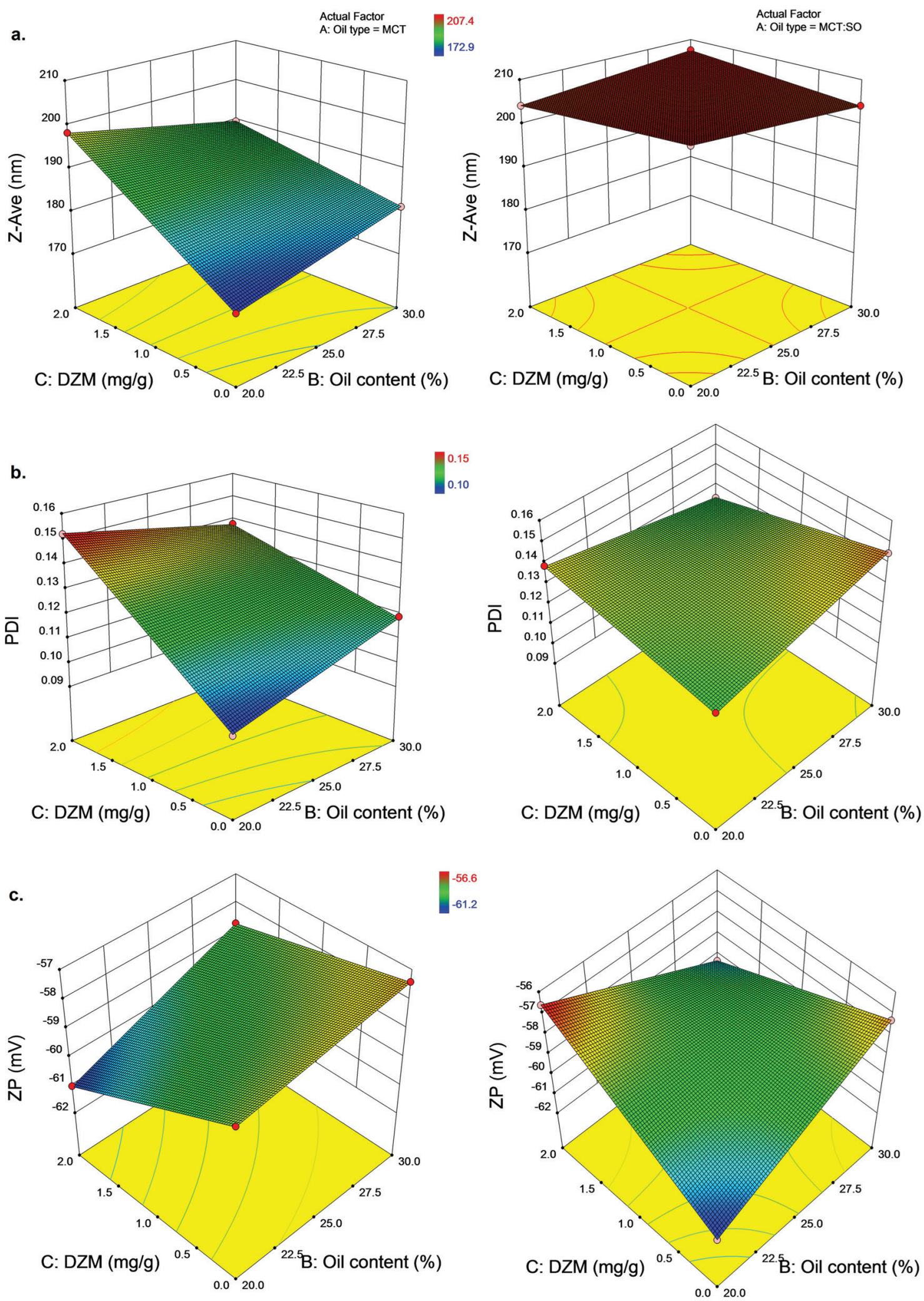

Figure 2. Response surface plots for the Z-Ave (a), PDI (b), and ZP (c) of nanoemulsions as a function of $B$ (oil content) and $C$ (drug presence) at both levels of $A$ (oil phase type). 
Drug-vehicle interactions and nanoemulsion characterization by DSC and FTIR

The effect of drug loading on the thermal behavior of the developed nanoemulsions and potential interactions among ingredients were examined using DSC technique. Fig. 3a shows DSC thermal curves obtained for the selected blank and DZM-loaded nanoemulsions, as well as for pure DZM. The DSC thermogram of pure DZM showed a sharp endothermic peak at $134.28^{\circ} \mathrm{C}$, corresponding to the melting of the drug. In the DSC curves of both DZM-loaded and unloaded nanoemulsions, a broad asymmetric endothermic peak was observed around $100^{\circ} \mathrm{C}$, most likely due to water evaporation. However, for DZMcontaining nanoemulsion, no melting peak of the drug was detected suggesting that DZM was molecularly dispersed in the oil phase of the nanoemulsion.

a.

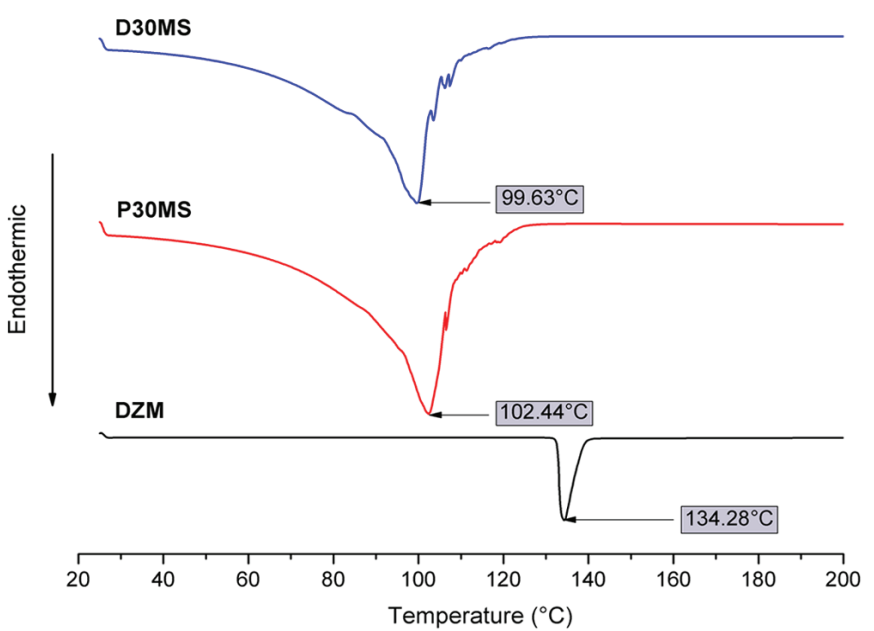

To complement the findings of the DSC, the FTIR spectroscopy was used as a supplementary technique for investigating intermolecular interactions in the developed nanoemulsion systems. Fig. 3b shows the FTIR spectra of blank and DZM-loaded nanoemulsions, as well as of pure DZM. The characteristic FTIR vibration bands observed in both, DZM-loaded and blank nanoemulsion spectra could be directly ascribed to the features deriving from oils and lecithin. Moreover, in the FTIR profile of DZM-loaded nanoemulsion, the specific peaks corresponding to the drug could not be detected - the DZM peaks disappeared or were buried in the peaks of oils. Also, there were no new peaks or shifts detected in this spectrum when compared to placebo nanoemulsion, confirming the absence of any chemical interaction of DZM with other nanoemulsion ingredients.

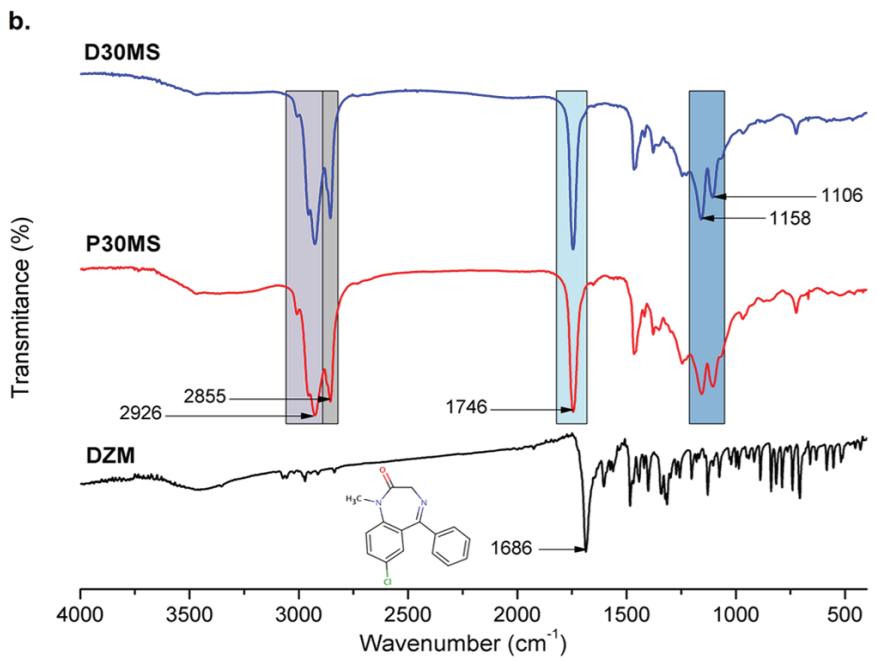

Figure 3. DSC thermograms (a) and FTIR spectra (b) of pure DZM, DZM-loaded (D30MS) and blank (P30MS) nanoemulsion.

\section{Stability study}

The physical stability of all nanoemulsions prepared according to the design of experiments was investigated after two months of storage at room temperature with respect to changes in size, size distribution, surface charge, electrical conductivity, and $\mathrm{pH}$ values. Data generated from the stability study (Table 3) showed that the droplet size, PDI, and ZP - the most representative parameters in the control of the emulsion stability - stayed practically unchanged during two months of storage for all investigated nanoemulsions (blank as well as DZM-loaded) formulated with MCT:SO mixture as the oil phase, reflecting their suitability for parenteral application. On the contrary, the stability of all nanoemulsions produced with MCT, except P30M, was significantly altered during the storage. For example, for placebo and DZM-loaded nanoemulsion formulations containing $20 \%$ of MCT (P20M, D20M), the phase separation was observed. On the other hand, although DZM-loaded nanoemulsion with $30 \%$ of MCT (D30M) did not demonstrate significant changes in ZAve and PDI, free oil droplets were seen on visual in- spection. From the results obtained, it can be suggested that the physical stability of nanoemulsions was possibly promoted by the presence of soybean oil.

The additional information about the storage stability of the investigated nanoemulsions was derived from the changes in $\mathrm{pH}$ and electrical conductivity over the evaluated period (Fig. 4). It should be noted that the $\mathrm{pH}$ of all nanoemulsion samples slightly, but significantly decreased $(p<0.05)$ during storage. This minor drop in nanoemulsion $\mathrm{pH}$ of about $0.3-0.6 \mathrm{pH}$ units could be explained by the increase in the free fatty acid content due to lecithin and oil hydrolytic degradation during storage. Concerning the electrical conductivity, a slight decrease was also observed, but there was no correlation between the change of this parameter and nanoemulsion instability. Combining all the stability parameters, we can conclude that currently developed nanoemulsions containing the mixture of MCT and SO as the oil phase were more robust and more stable than those with MCT. 


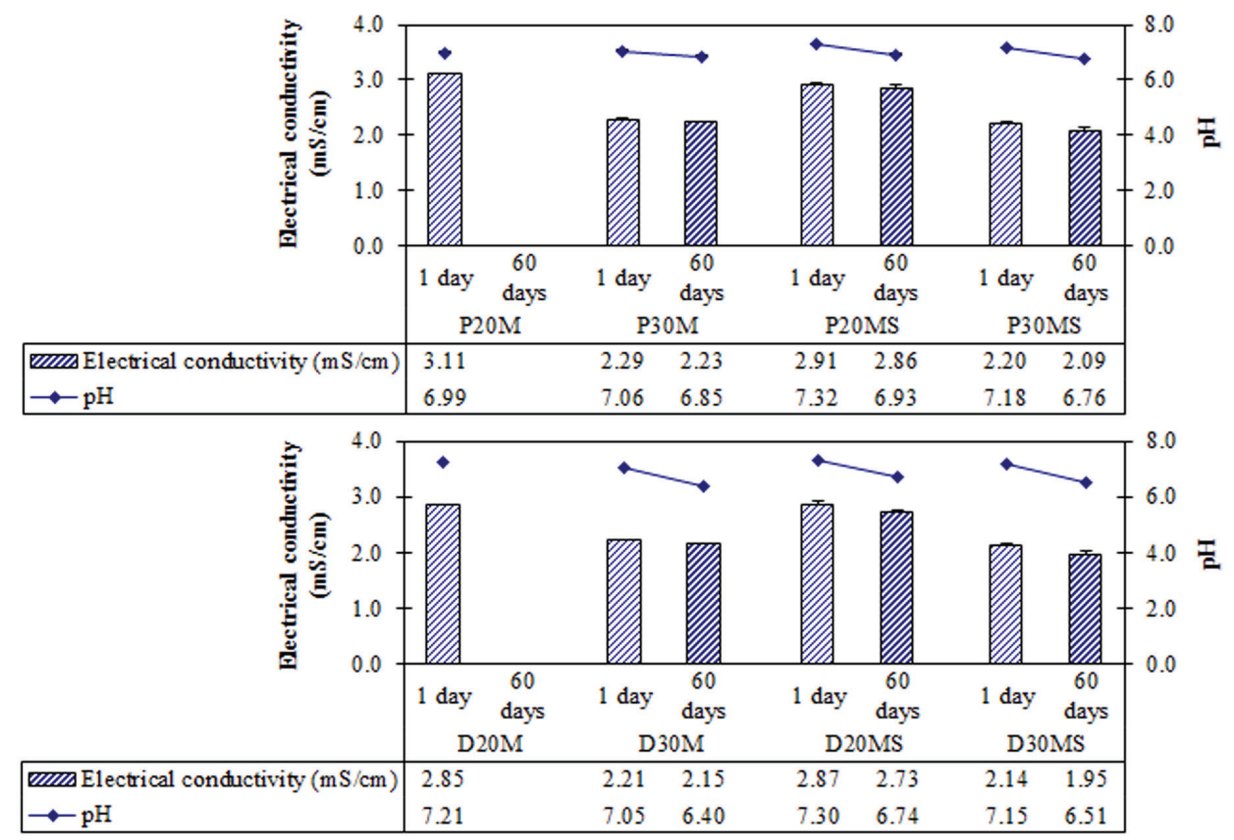

Figure 4. $\mathrm{pH}$ values and electrical conductivity of nanoemulsions one day after preparation and after two months of storage at $25^{\circ} \mathrm{C}$ (mean $\pm \mathrm{SD}, \mathrm{n}=3$ ).

\section{Conclusions}

In this work, a systematic design of experiments approach was successfully applied to better understanding of the formulation of nanoemulsions as potential carriers for parenteral delivery of psychopharmacological drugs. Placebo and drug-loaded nanoemulsions stabilized by the lecithin/polysorbate 80 mixture and containing 20 or $30 \%$ of the MCT or MCT:SO mixture as the oil phase, using DZM as a model drug were prepared by cold $\mathrm{HPH}$. After preparation, all formulations revealed a small droplet size (Z-Ave about $200 \mathrm{~nm}$ ) with the narrow droplet size distribution (PDI < 0.15) and $\mathrm{ZP}$ around $-60 \mathrm{mV}$.

The results of the performed full factorial design showed significant main, as well as interaction effects of the tested factors (oil type, oil content, drug presence) affecting nanoemulsion critical quality attributes (Z-Ave, PDI, ZP). DSC and FTIR analyses indicated that DZM was molecularly dispersed in the investigated nanoemulsions, without chemical interactions with other ingredients. Based on nanoemulsion physicochemical properties and stability during 2 months of storage at $25^{\circ} \mathrm{C}$, developed nanoemulsions containing MCT:SO mixture $(4: 1, \mathrm{w} / \mathrm{w})$ could be considered as promising carriers for parenteral drug delivery.

\section{Acknowledgments}

This work was financially supported by the Ministry of Education, Science and Technological Development, Republic of Serbia, within the framework of the Projects TR34031 and TR34012. The authors are grateful to Lipoid $\mathrm{GmbH}$ for supplying Lipoid Purified Soybean Oil 700 and Lipoid S 75.

\section{References}

[1] V. Klang, C. Valenta, Lecithin-based nanoemulsions, Journal of Drug Delivery Science and Technology, 21(1) (2011) 55 - 76.

[2] F. A. Araújo, R. G. Kelmann, B. V. Araújo, R. B. Finatto, H. F. Teixeira, L. S. Koester, Development and characterization of parenteral nanoemulsions containing thalidomide, European Journal of Pharmaceutical Sciences, 42(3) (2011) 238 - 245.

[3] H. Zhou, Y. Yue, G. Liu, Y. Li, J. Zhang, Q. Gong, Z. Yan, M. Duan, Preparation and characterization of a lecithin nanoemulsion as a topical delivery system, Nanoscale Research Letters, 5(1) (2010) 224 - 230.

[4] K. Hippalgaonkar, S. Majumdar, V. Kansara, Injectable lipid emulsions-Advancements, opportunities and challenges, AAPS PharmSciTech, 11(4) (2010) 1526 1540.

[5] N. Sadurní, C. Solans, N. Azemara, M. J. GarcíaCelma, Studies on the formation of O/W nano-emulsions, by low-energy emulsification methods, suitable for pharmaceutical applications, European Journal of Pharmaceutical Sciences, 26(5) (2005) 438 - 445.

[6] S. Benita, M. Y. Levy, Submicron emulsions as colloidal drug carriers for intravenous administration: comprehensive physicochemical characterization, Journal of Pharmaceutical Sciences, 82(11) (1993) 1069 - 1079.

[7] X. Li, L. Du, C. Wang, Y. Liu, X. Mei, Y. Jin, Highly efficient and lowly toxic docetaxel nanoemulsions for intravenous injection to animals, Pharmazie, 66(7) (2011) 479 - 483.

[8] S. M. Đorđević, T. S. Radulović, N. D. Cekić, D. V. Ranđelović, M. M. Savić, D. R. Krajišnik, J. R. Milić, S. D. Savić, Experimental design in formulation of diazepam nanoemulsions: Physicochemical and pharmacokinetic performances, Journal of Pharmaceutical Sciences, 102(11) (2013) 4159 - 4172.

[9] E. Yilmaz, H. H. Borchert, Design of a phytosphingosine- 
containing, positively-charged nanoemulsion as a colloidal carrier system for dermal application of ceramides, European Journal of Pharmaceutics and Biopharmaceutics, 60(1) (2005) 91 - 98.

[10] M. Jumaa, B. W. Müller, Parenteral emulsions stabilized with a mixture of phospholipids and PEG-660-12hydroxy-stearate: evaluation of accelerated and longterm stability, European Journal of Pharmaceutics and Biopharmaceutics, 54(2) (2002) 207 - 212.

[11] T. P. Nordén, B. Siekmann, S. Lundquist, M. Malmsten, Physicochemical characterisation of a drug containing phospholipid-stabilised o/w emulsion for intravenous administration, European Journal of Pharmaceutical Sciences, 13(4) (2001) 393 - 401.

[12] R. G. Kelmann, G. Kuminek, H. F. Teixeira, L. S. Koester, Carbamazepine parenteral nanoemulsions prepared by spontaneous emulsification process, International Journal of Pharmaceutics, 342(1-2) (2007) 231 - 239.

[13] D. Marín-Quintero, F. Fernández-Campos, A. C. CalpenaCampmany, M. J. Montes-López, B. Clares-Naveros, A. Del Pozo-Carrascosa, Formulation design and optimization for the improvement of nystatin-loaded lipid intravenous emulsion, Journal of Pharmaceutical Sciences, 102(11) (2013) 4015 - 4023.

[14] K. Gao, J. Sun, K. Liu, X. Liu, Z. He. Preparation and characterization of a submicron lipid emulsion of docetaxel: Submicron lipid emulsion of docetaxel, Drug
Development and Industrial Pharmacy, 34(11) (2008) $1227-1237$.

[15] M. Jumaa, B. W. Müller, The effect of oil components and homogenization conditions on the physicochemical properties and stability of parenteral fat emulsions, International Journal of Pharmaceutics, 163(1-2) (1998) $81-89$.

[16] R. H. Müller, S. Schmidt, I. Buttle, A. Akkar, J. Schmitt, S. Brömer, SolEmuls ${ }^{\circledR}$ —novel technology for the formulation of i.v. emulsions with poorly soluble drugs, International Journal of Pharmaceutics, 269(3) (2004) 293 - 302.

[17] C. Vitorino, F. A. Carvalho, A. J. Almeida, J. J. Sousa, A. A Pais, The size of solid lipid nanoparticles: An interpretation from experimental design, Colloids and Surfaces. B: Biointerfaces, 84(1) (2011) 117 - 130.

[18] I. Solè, C. M. Pey, A. Maestro, C. González, M. Porras, C. Solans, J. M. Gutiérrez, Nano-emulsions prepared by the phase inversion composition method: Preparation variables and scale up, Journal of Colloid and Interface Science, 344(2) (2010) 417 - 423.

[19] J. J. Wang, K. C. Sung, O. Y. Hu, C. H. Yeh, J. Y. Fang, Submicron lipid emulsion as a drug delivery system for nalbuphine and its prodrugs, Journal of Controlled Release, 115(2) (2006) 140 - 149.

Izvod

\section{PUN FAKTORSKI DIZAJN U FORMULACIJI PARENTERALNIH NANOEMULZIJA SA DIAZEPAMOM: FIZIČKOHEMIJSKA KARAKTERIZACIJA I PROCENA STABILNOSTI}

Nebojša D. Cekić ${ }^{1,2}$, Sanela M. Đorđević3, ${ }^{3,}$, Saša R. Savić ${ }^{1}$, Snežana D. Savić ${ }^{3}$

${ }^{1}$ Tehnološki fakultet, Univerzitet u Nišu, Leskovac, Srbija

(ORIGINALNI NAUČNI RAD)

2DCP Hemigal, Leskovac, Srbija

${ }^{3}$ Katedra za farmaceutsku tehnologiju i kozmetologiju, Farmaceutski fakultet, Univerzitet u Beogradu, Beograd, Srbija UDK 615.214.24

Cilj ovog rada bio je da se primenom metodologije eksperimentalnog dizajna razviju parenteralne nanoemulzije sa diazepamom kao model lekovitom supstancom i da se sprovede njihova sveobuhvatna fizičkohemijska karakterizacija. Metodom homogenizacije pod visokim pritiskom na sobnoj temperaturi izrađene su placebo i nanoemulzije sa lekom, stabilizovane smešom lecitina i polisorbata 80 , variranjem udela i vrste uljane faze -20 i $30 \%(\mathrm{~m} / \mathrm{m})$ triglicerida srednje dužine lanca ili smeše triglicerida srednje dužine lanca i sojinog ulja u odnosu 4:1. Dobijene nanoemulzije okarakterisane su u pogledu veličine i raspodele veličina kapi, površinskog naelektrisanja, interakcija lek-nosač i fizičke stabilnosti. U cilju procene istovremenog uticaja vrste uljane faze, udela ulja i prisustva leka, kao i njihovih interakcija, na kritične atribute kvaliteta nanoemulzija, primenjen je pun faktorski dizajn sa tri faktora na dva nivoa.

Nakon izrade, sve formulacije nanoemulzija imale su malu veličinu kapi u opsegu $170-210 \mathrm{~nm}$, sa veoma uskom raspodelom veličina (ispod 0,15 ) i površinskim naelektrisanjem oko $-60 \mathrm{mV}$. Rezultati eksperimentalnog dizajna pokazali su da ne samo pojedinačni faktori (vrsta ulja, koncentracija ulja, prisustvo leka), nego i njihove interakcije, značajno utiču na veličinu kapi, indeks polidisperznosti i zeta potencijal ispitivanih nanoemulzija. Tokom 2 meseca čuvanja na $25^{\circ} \mathrm{C}$, sve nanoemulzije formulisane sa smešom triglicerida srednje dužine lanca i sojinog ulja kao uljanom fazom bile su fizički stabilne, bez značajnih promena u praćenim parametrima. Fizičkohemijske karakteristike i stabilnost navedenih nanoemuIzija ukazuju da one mogu biti potencijalni nosači za parenteralnu isporuku lekovitih supstanci.
Ključne reči: nanoemulzija; diazepam; eksperimentalni dizajn; parenteralna isporuka; fizička stabilnost. 